Int. J. Morphol.,

34(2):713-718, 2016.

\title{
Tribulus terrestris Hydroalcoholic Extract Effect on Cisplatin-Induced Apoptosis in Mice Kidney
}

\author{
Efecto del Extracto Hidroalcohólico de Tribulus terrestris sobre la \\ Apoptosis Inducida por Cisplatino en el Riñón de Ratones
}

Ali Ghanbari"; Fatemeh Zare**; Mozafar Khazaei"; Mojtaba Moradi" \& Amir Raoofi***

GHANBARI, A.; ZARE, F.; KHAZAEI, M.; MORADI, M. \& RAOOFI,A. Tribulus terrestris hydroalcoholic extract effect on cisplatininduced apoptosis in mice kidney. Int. J. Morphol., 34(2):713-718, 2016.

SUMMARY: Cisplatin (EBEWE Pharma, Unterach, Austria) is an anti-cancer drug used in chemotherapy. One of the limiting major side effects of cisplatin is nephrotoxicity. Tribulus terrestris (TT) has been used as an synthetic or herbal protective agents for kidney disorders. The present study amid to investigate the Tribulus terrestris Hydroalcoholic extract effect on cisplatin-induced apoptosis in mice kidney. Male adult mice $(n=30)$ were divided into control group and 4 experimental groups $(n=6)$. Control group received saline, the first experimental group received cisplatin $(5.5 \mathrm{mg} / \mathrm{kg})$ and other three experimental groups received cisplatin $(5.5 \mathrm{mg} / \mathrm{kg})$ and different doses of hydroalcoholic extact of TT (100, 300 and $500 \mathrm{mg} / \mathrm{kg}$ i.p) respectively. The kidneys were removed after 4 days of injections, and TUNEL assay on mice's kidneys were performed. Weights of body and kidneys and apoptotic index were assessed. Data analysis was performed using one-way ANOVA followed by Tukey's post hoc test. The results showed that cisplatin lead to a reduction in the weight of body and kidney $(\mathrm{P}<0.01)$, and increased apoptotic index significantly compared to the control group $(\mathrm{P}<0.001)$, while in treated groups with TT, the weights of body and kidney were significantly higher compared with cisplatin group, but apoptotic index did not show significant differences. These parameters reached normal range after administration of fruit extracts of TT for 4 days. The study demonstrates that extract of TT could have protective effect on cisplatin- induced apoptosis of kidney. This may be related to the presence of antioxidant components acting via a multitude of central and peripheral mechanisms.

KEY WORDS: Cisplatin; Nephrotoxicity; Tribulus terrestris; Kidneys; Protective effect.

\section{INTRODUCTION}

Cisplatin (cis-diamminedichloroplatinum II) (CP), a most effective chemotherapeutic agent, has been successfully used in treatment of a variety of solid tumors, including ovary, testis, bladder, head and neck, lung, cervix, and endometrium (Baek et al., 2003; Hadjzadeh et al., 2012). It is an efficient platinum-derived alkylating agent that acts in unspecific phases of the cellular cycle against proliferating and resting cells (Lirdi et al., 2008) However, the use of dose intensification CP is limited by major side effects such as nephrotoxicity, peripheral neuropathy, ototoxicity, azoospermia, sperm morphology and motility alterations in normal tissues (Lirdi et al.; Pabla \& Dong, 2008). CP nephrotoxicity pathological feature, the major adverse effect of $\mathrm{CP}$ in approximately one third of patients during chemotherapy in clinic, it has been the cause of renal cell damage, cell death and the loss of renal function or acute renal failure, especially in renal tubules (Jiang $e t$ al., 2009; Ramesh \& Reeves, 2002; Sheikh-Hamad et al., 2004; Arjumand et al., 2011; Kang et al., 2011; Arany \& Safirstein, 2003; Pabla \& Dong). Oxidative agents, principally involving reactive oxygen species (ROS) in renal tubular cells, are considered as the main mechanisms of nephrotoxicity of CP. The interaction of ROS with cellular components may lead to injury DNA, proteins and lipids (An et al., 2001; Matsushima et al., 1998). Depending on $\mathrm{CP}$ administration dose and cellular status, tubular cell death has been known in the forms of both apoptosis and necrosis, albeit the mechanism basic cisplatin-induced tubular cell death is not thoroughly discerned (Pabla \& Dong). To avoid this side effect,

\footnotetext{
Fertility and Infertility Research Center, Kermanshah University of Medical Sciences, Kermanshah, Iran.

** MSc in Anatomy, Shahid beheshti University of Medical Sciences, Tehran, Iran.

*** Ph.D in Anatomy, Shahid beheshti University of Medical Sciences, Tehran, Iran \& Fertility and Infertility Research Center, Kermanshah University of Medical Sciences, Kermanshah, Iran.
} 
prescription of complementary synthetic or herbal protective agents has been investigated against $\mathrm{CP}$-induced nephrotoxicity (Saleh et al., 2009; Naqshbandi et al., 2012; Ashrafi et al., 2012; Pérez-Rojas et al., 2011). Tribulus terrestris $\mathrm{L}$ (popularly known as puncture vine) is an annual herb of the Zygophyllacea family about 30-70 cm high and has pinnate leaves (of unequal length), yellow flowers and characteristic stellate shaped carpel fruit (Rajendar et al., 2011; Singh, et al., 2012; Sharma et al., 2013). Tribulus terrestris $\mathrm{L}$ grows with a wide distribution in tropical and moderate areas, including the US and Mexico, the Mediterranean region, and throughout Asia (Phillips et al., 2006; Chu et al., 2003). A fruit of traditional Chinese medicine (Sugunavarman et al., 2010), the plant extract is mainly used for kidney disorders. Different parts of Tribulus terrestris $\mathrm{L}$ have been used traditionally in treating a variety of diseases including hypertension and coronary artery diseases, diabetes and hyperlipidemia, as well as fungal diseases (Sharma et al.; Phillips et al.; Chu et al.; Sugunavarman et al.). In addition it has been shown that Tribulus terrestris $\mathrm{L}$ extract has antioxidative, apoptosis inhibitory, and vasodilator properties (Shalaby \& Hammouda, 2014; Kavitha et al., 2011). The fruit removes gravel from the urine and stone in the bladder (Kavitha \& Jagadeesan, 2006). Tribulus terrestris $\mathrm{L}$ is also reported to have cooling, diuretic, tonic and aphrodisiac effects (Sugunavarman et al.). Accordingly, it is of particular interest to discover the effects of Tribulus terrestris $\mathrm{L}$ on cisplatin-induced apoptosis in mice kidney.

\section{MATERIAL AND METHOD}

Collection and preparation of aqueous extract. Whole plants were purchased from a traditional medicine center in June 2013 and identified and authenticated by a botanist. Then, fresh fruits of $T$. terrestris $\mathrm{L}$ were dried in shade at room temperature $\left(25 \pm 2{ }^{\circ} \mathrm{C}\right)$ and its extract was obtained through the percolati on method. Extracting method was described previously (Keshtmand et al., 2015). With this method, approximately $200 \mathrm{~g}$ of the dry plant specimen was ground and added to $400 \mathrm{~mL}$ of $70 \%$ ethanol and were left to macerate at room temperature for $4 \mathrm{~h}$. Then, the tinctured grains were extracted by percolation method and extract concentrated in a vacuum and dried in the flat surface. The obtained extract weight, $6.5 \mathrm{~g}$ was expressed as $\mathrm{mg} / \mathrm{kg}$ of body weight for 4 days followed by CIS injection. After dissolving the extract in distilled water, extract was immediately administered interaperitoneally to mice.

Drugs. Cis-diammineplatinum (II) dichloride (cisplatin) from Ebeve Pharma (Austria) was purchased. Ten to fifteen minutes before use, $\mathrm{CP}$ was dissolved in saline in darkness. At one day of the experiment an intraperitoneal injection $(5.5 \mathrm{mg} / \mathrm{kg}$ ) was given (Raoofi et al., 2015).

Animal experiment and Groups. Thirty male Balb/c mice (weight, $25 \mathrm{~g}$ to $30 \mathrm{~g}$ ) were procured from animal house of Kermanshah University of Medical Sciences. The mice were maintained in a 12-h light/dark cycle in a temperature and humidity controlled facility without any stressful stimuli. The animals were provided with standard diet pellets and water ad libitum. Experiments were started after one week of adaptation. Research protocols were approved by the local ethics committee. Mice were distributed at random into five groups (each of six mice) and individually put in metabolic cages and treated as follows: (i) control group (C) received normal saline $(0.9 \% \mathrm{NaCl})$; (ii) Experimental groups Consist of cisplatin-treated group (E1): one injection of cisplatin ( $5 \mathrm{mg} / \mathrm{kg}$ body weight, i.p), $T$. terrestris -cisplatin-treated groups (TT + CIS): CIS + 100 $\mathrm{mg} / \mathrm{kg}$ extract of TT (E2), CIS $+300 \mathrm{mg} / \mathrm{kg}$ extract of TT (E3), CIS $+500 \mathrm{mg} / \mathrm{kg}$ extract of TT (E4). Body weights of the mice were recorded initially and at the end of the experimental procedure (day 5). Weights of the kidneys were also noted.

TUNEL Method. The DNA 30-end labeling of apoptotic cells was detected by the terminal deoxynucleotidyl transferase-mediated deoxyuridine triphosphate nick endlabeling (TUNEL) assay by using In situ Cell Death Detection Kit, AP (Roche Diagnostics Deutschland GmbH, Germany; 17848651). Sections were dewaxed with xylene and rehydrated by standard methods and washed in deionized water. Nuclei in the tissue sections were excluded from protein by incubating with $50 \mu \mathrm{L}$ of proteinase $\mathrm{K}$ (10 $\mathrm{mg} / \mathrm{mL}$ ) for $20 \mathrm{~min}$ at $37^{\circ} \mathrm{C}$. After washing with phosphate buffered saline PBS (10 min, twice), the slides were incubated with TUNEL reaction mixture in a humidified chamber at $37^{\circ} \mathrm{C}$ for $60 \mathrm{~min}$, followed by rinsing with PBS for (10 min, three times). The sections were counterstained with propidium iodide solution diluted to $1 \mu \mathrm{g} / \mathrm{mL}$ in PBS (15 min), and then washed in deionized water (5 min). Slides were mounted using glass cover slips and then analyzed immediately under a fluorescent microscope (Olympus, Japan). Apoptotic index (AI) was calculated by dividing the number of TUNEL positive cells to total number of the cells in randomly selected fields, and the result was multiplied by 100 (Lirdi et al.).

Data analysis. In this experimental study all Data were recorded as Mean \pm SE. the one way analysis of variance with Tukey's post hoc test was used to determine differences between control and experimental groups. P $<0.05$ was regarded as statistically significant. 


\section{RESULTS}

After 4 days of injections CIS in a dose of $5.5 \mathrm{mg} /$ $\mathrm{kg}(\mathrm{E} 1)(\mathrm{P}=0.004)$ and CIS $+100 \mathrm{mg} / \mathrm{kg}$ extract of TT (E2) $(\mathrm{P}=0.011)$ to male mice of the experiment induced significant decreases in weight of the total body when compared to the normal control group (Fig. 1). The weight of the kidneys in comparison with control group were significantly decreased in $\mathrm{E} 1(\mathrm{P}=0.002)$ group but there was not changed in other ones $(\mathrm{P}>0.05)$ (Fig. 2).

Renal tubular apoptosis has been suggested as a mechanism of cisplatin-induced acute kidney injury. The TUNEL method detects DNA fragmentation associated with late apoptosis. The TUNEL staining sections of the kidneys revealed that apoptosis occurred in both cortex and medulla of CP involved groups. Calculated apoptotic index based on these sections showed this occurrence significantly increased in E1group $(\mathrm{P}<0.001)$ and CIS + $100 \mathrm{mg} / \mathrm{kg}$ extract of TT groups ( $\mathrm{P}<0.01)$ (Figs. 3 and 4$)$. As shown in Figure 3, in the CIS + 300 TT and CIS + 500 TT treatment groups there were no significant changes in renal tubular apoptosis (Figs. 3 and 4).

\section{DISCUSSION}

The present study demonstrated $T$. terrestris hydroalcoholic extract effect on cisplatin-induced apoptosis in mice kidney. Treatment of mice with $\mathrm{CP}$ resulted in renal damage, showing a significant decline in the weight of animals treated with CP. These data supported other studies that indicated reductions in body weight could be attributable to toxic side effect of chemotherapeutic drugs and it suggests that $T$. terrestris relieves the adverse effects of CP (Raoofi et al.). In the present study, we determined DNA fragmentation in kidney using the TUNEL technique. A single dose of CP caused apoptosis in kidney. It seems that inflammatory responses with regard to the weight of animals are acute consequence of CIS administration that occurs during 3-4 days after exposure (Ueki et al., 2013). In vivo administration of nephrotoxic doses of CP produces a large increase in apoptosis in the kidney (Ramesh \& Reeves, 2004). Previous studies showed that CP upregulates the expression of TNF- $\alpha$ in mouse kidney and TNF- $\alpha$ stimulates an inflammatory response in vivo which exacerbates cisplatin nephrotoxicity (Ramesh \& Reeves, 2003). Treatment of cisplatin-treated mice with $T$. terrestris significantly improved renal dysfunction, reducing tubular cell damage, oxidative stress and apoptosis. Thus, together with other herbal extracts, T. terrestris reduces apoptosis

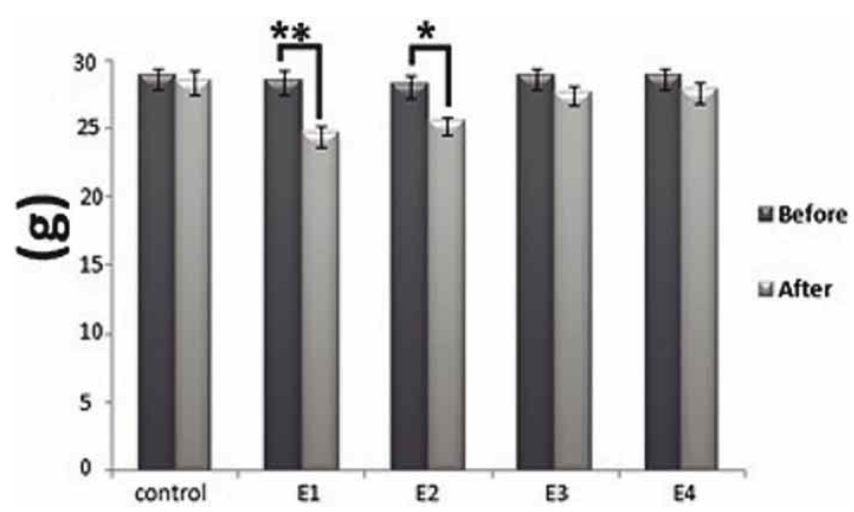

Fig. 1. The effect of toxic dose of cisplatin (CIS) $(5.5 \mathrm{mg} / \mathrm{kg})$ and different doses of Tribulus Terrestris (TT) on total body weights in the mice (left bar of the pairs is initial weights and the right bar is end weights). The groups ( $\mathrm{X}$ axis) are control: not treated, E1: CIS, $\mathrm{E} 2: \mathrm{CIS}+\mathrm{TT}(100 \mathrm{mg} / \mathrm{kg}), \mathrm{E} 3: \mathrm{CIS}+\mathrm{TT}(300 \mathrm{mg} / \mathrm{kg}), \mathrm{E} 4: \mathrm{CIS}+$ $\mathrm{TT}(500 \mathrm{mg} / \mathrm{kg}) . *=\mathrm{P}<0.05, * *=\mathrm{P}<0.01$.

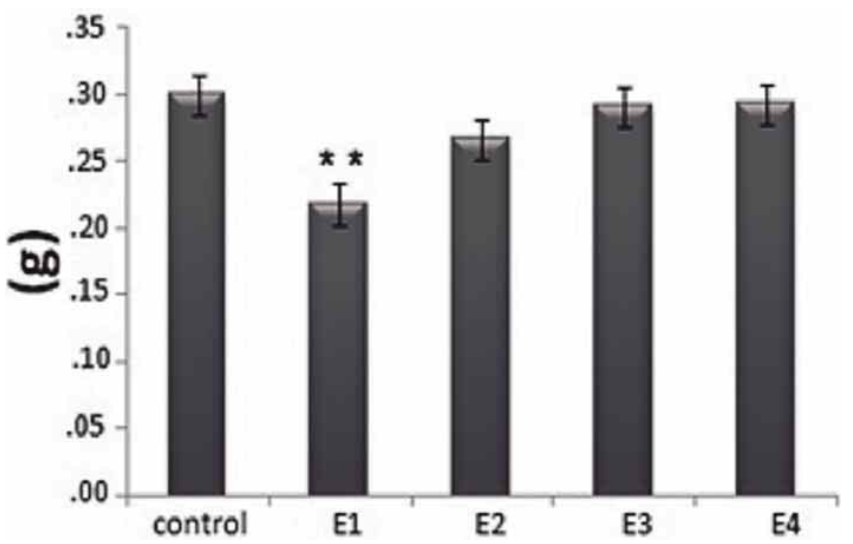

Fig. 2. The effect of toxic dose of cisplatin (CIS) $(5.5 \mathrm{mg} / \mathrm{kg})$ and different doses of Tribulus terrestris (TT) on the kidney weights. The groups (X axis) are Control: not treated, E1: CIS, E2: CIS + TT $(100 \mathrm{mg} / \mathrm{kg}), \mathrm{E} 3: \mathrm{CIS}+\mathrm{TT}(300 \mathrm{mg} / \mathrm{kg}), \mathrm{E} 4: \mathrm{CIS}+\mathrm{TT}(500 \mathrm{mg} /$ $\mathrm{kg}) . * *=\mathrm{P}<0.01$ in comparison with the control group.

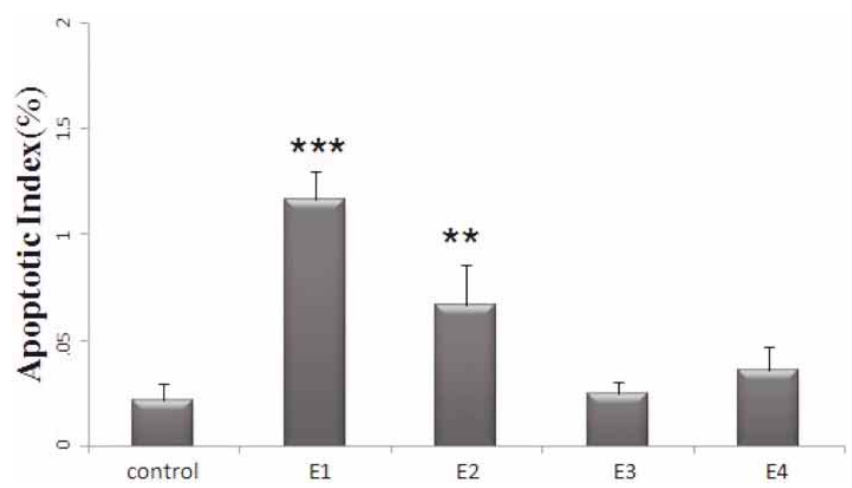

Fig. 3. The effect of toxic dose of cisplatin $(5.5 \mathrm{mg} / \mathrm{kg})$ and different doses of Tribulus terrestris (TT) on apoptotic index of kidneys. The groups (X axis) are Control: not treated, E1: CIS, E2: CIS + TT (100 $\mathrm{mg} / \mathrm{kg}), \mathrm{E} 3: \mathrm{CIS}+\mathrm{TT}(300 \mathrm{mg} / \mathrm{kg}), \mathrm{E} 4: \mathrm{CIS}+\mathrm{TT}(500 \mathrm{mg} / \mathrm{kg})$. $* *=$ $\mathrm{P}<0.01$, *** $=\mathrm{P}<0.001$ in comparison with the control group. 


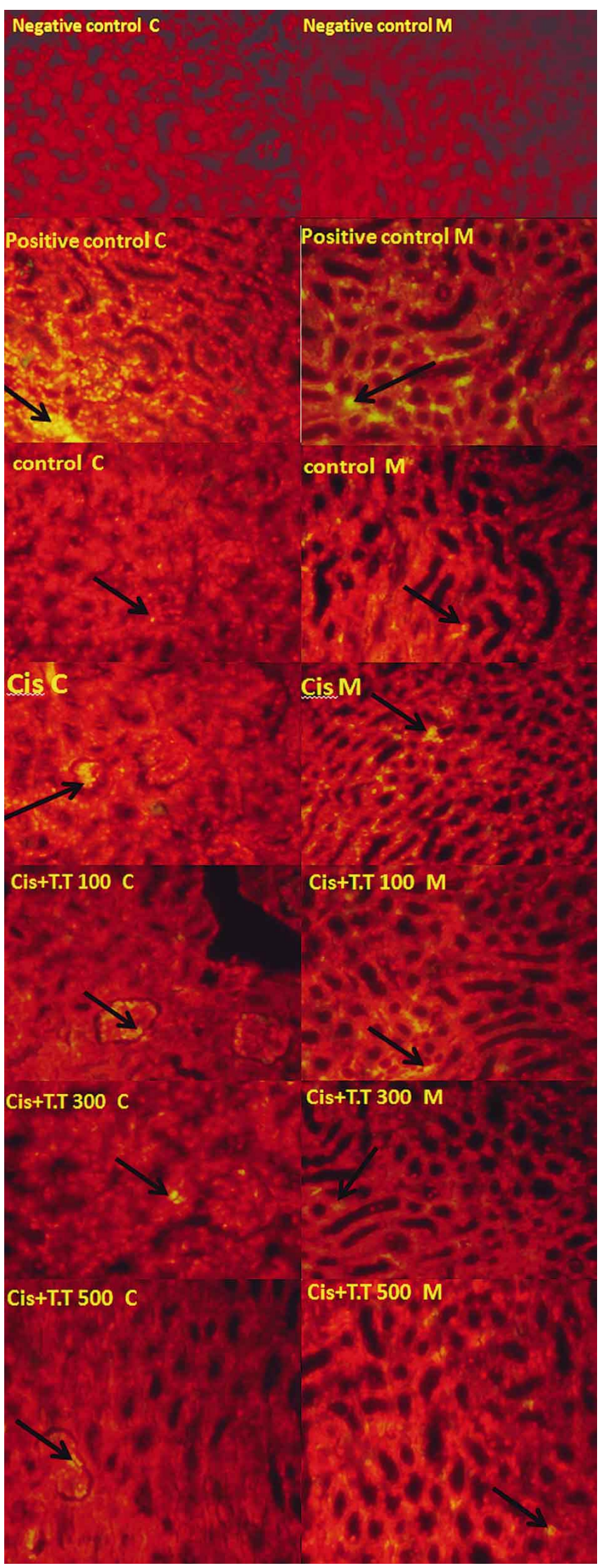

of $\mathrm{CP}$ by decreasing the number of apoptotic cells that can be considered as the antioxidant activity or diuretic effect of $T$. terrestris. The antioxidant activity of T. terrestris could be attributed to its flavonoid content (Harborne \& Williams, 2000). A number of studies have shown that flavonoids have the ability to regulate a variety of enzyme systems involved in cell division, proliferation, detoxification, inflammation and immune response (Choi et al., 2004; Di Carlo et al., 1999; Hollman \& Katan, 1999). In summary, we demonstrated that $\mathrm{CP}$ nephrotoxicity is the composite result of the transport of $\mathrm{CP}$ into renal epithelial cells, injury to nuclear and mitochondrial DNA and Finally Induction apoptosis. In conclusion, our previous and present studies indicate that the antioxidant action of T. terrestris prevents of renal cell death by apoptosis and necrosis. Treatment of male mice with extract of $T$. terrestris showed obvious effects on the kidney studied.

\section{ACKNOWLEDGMENTS}

The authors thank Fertility and Infertility Research Center (FIRC) employees for facility support. This paper is financially supported by Kermanshah University Medical Sciences (Grant no. 91400).

GHANBARI, A.; ZARE, F.; KHAZAEI, M.; MORADI, M. \& RAOOFI, A. Efecto del extracto hidroalcohólico de Tribulus terrestris sobre la apoptosis inducida por cisplatino en el riñón de ratones. Int. J. Morphol., 34(2):713-718, 2016.

RESUMEN: El cisplatino (EBEWE Pharma, Unterach, Austria) es un medicamento contra el cáncer utilizado en quimioterapia. Uno de los principales efectos secundarios limitantes del cisplatino es la nefrotoxicidad. Tribulus terrestris (TT) ha sido utilizado como agente protector sintético o herbal para los trastornos renales. El objetivo fue investigar el efecto del extracto hidroalcohólico de TT sobre la apoptosis inducida por cisplatino en el riñón de ratones. Se utilizaron ratones adultos machos $(n=30)$, que fueron divididos en 4 grupos, un control y tres grupos experimentales $(n=6)$. El grupo control recibió solución salina; el primer grupo experimental recibió cisplatino $(5,5$ $\mathrm{mg} / \mathrm{kg}$ ) y los otros tres grupos experimentales recibieron

Fig. 4. The effect of toxic dose of cisplatin $(5.5 \mathrm{mg} / \mathrm{kg})$ and different doses of Tribulus terrestris on cortex and medulla of the kidneys of male balb/c mice (TUNEL staining, Arrows show TUNEL positive cells, Photos represent X200 magnification). 
cisplatino $(5,5 \mathrm{mg} / \mathrm{kg})$ con diferentes dosis de extracto hidroalcohólico de TT (100, 300 y $500 \mathrm{mg} / \mathrm{kg}$ vía ip) respectivamente. Los riñones fueron retirados después de 4 días de aplicadas las inyecciones, y se realizó el ensayo TUNEL en los riñones. Se evaluó el peso corporal de los ratones, el peso de los riñones y el índice de apoptosis. El análisis de datos se realizó mediante ANOVA de un factor seguido por la prueba post hoc de Tukey. Los resultados mostraron que el cisplatino con plomo provocó una reducción en el peso corporal y el riñón $(\mathrm{P}<0,01)$ y un aumento significativo del índice de apoptosis en comparación con el grupo control (P $<0,001$ ), mientras que en los grupos tratados con TT, los pesos corporales y de los riñones fueron significativamente mayores en comparación con el grupo de cisplatino, pero el índice de apoptosis no mostró diferencias significativas. Estos parámetros alcanzaron niveles normales después de la administración de extracto de TT durante 4 días. El estudio demuestra que el extracto de TT podría tener un efecto protector sobre la apoptosis inducida por cisplatino en el riñón, que podría estar relacionado con la presencia de componentes antioxidantes que actúan a través de múltiples mecanismos centrales y periféricos.

PALABRAS CLAVE: Cisplatino; Nefrotoxicidad; Tribulus terrestris; Riñones; Efecto protector.

\section{REFERENCES}

An, Y.; Xin, H.; Yan, W. \& Zhou, X. Amelioration of cisplatininduced nephrotoxicity by pravastatin in mice. Exp. Toxicol. Pathol., 63(3):215-9, 2011.

Arany, I. \& Safirstein, R. L. Cisplatin nephrotoxicity. Semin. Nephrol., 23(5):460-4, 2003.

Arjumand, W.; Seth, A. \& Sultana, S. Rutin attenuates cisplatin induced renal inflammation and apoptosis by reducing NFkB, TNF-a and caspase-3 expression in wistar rats. Food Chem. Toxicol., 49(9):2013-21, 2011.

Ashrafi, F.; Nematbakhsh, M.; Safari, T.; Talebi, A.; Nasri, H.; Khazaei, M.; Baradaran-Mahdavi, M. M.; Jafapisheh, A.; Olia, B.; Pirhaji, O.; Hashemi-Nia, S. J.; Eshraghi, F.; Pezeshki, Z. \& Mortazavi, M. A combination of vitamin C and losartan for cisplatin-induced nephrotoxicity in rats. Iran. J. Kidney Dis., 6(5):361-5, 2012.

Baek, S. M.; Kwon, C. H.; Kim, J. H.; Woo, J. S.; Jung, J. S. \& Kim, Y. K. Differential roles of hydrogen peroxide and hydroxyl radical in cisplatin-induced cell death in renal proximal tubular epithelial cells. J. Lab. Clin. Med., 142(3):178-86, 2003.

Choi, J. S.; Choi, Y. J.; Park, S. H.; Kang, J. S. \& Kang, Y. H. Flavones mitigate tumor necrosis factor-alpha-induced adhesion molecule upregulation in cultured human endothelial cells: role of nuclear factor-kappa B. J. Nutr., 134(5):1013-9, 2004.
Chu, S.; Qu, W.; Pang, X.; Sun, B. \& Huang, X. Effect of saponin from Tribulus terrestris on hyperlipidemia. Zhong Yao Cai, 26(5):341-4, 2003.

Di Carlo, G.; Mascolo, N.; Izzo, A. A. \& Capasso, F. Flavonoids: old and new aspects of a class of natural therapeutic drugs. Life Sci., 65(4):337-53, 1999.

Hadjzadeh, M. A.; Keshavarzi, Z.; Tabatabaee Yazdi, S. A.; Ghasem Shirazi, M.; Rajaei, Z. \& Khajavi Rad, A. Effect of alcoholic extract of Nigella sativa on cisplatin-induced toxicity in rat. Iran. J. Kidney Dis., 6(2):99-104, 2012.

Harborne, J. B. \& Williams, C. A. Advances in flavonoid research since 1992. Phytochemistry, 55(6):481-504, 2000.

Hollman, P. C. \& Katan, M. B. Dietary flavonoids: intake, health effects and bioavailability. Food Chem. Toxicol., 37(9-10):93742, 1999.

Jiang, M.; Wang, C. Y.; Huang, S.; Yang, T. \& Dong, Z. Cisplatininduced apoptosis in p53-deficient renal cells via the intrinsic mitochondrial pathway. Am. J. Physiol. Renal Physiol., 296(5):F983-93, 2009.

Kang, K. P.; Park, S. K.; Kim, D. H.; Sung, M. J.; Jung, Y. J.; Lee, A. S.; Lee, J. E.; Ramkumar, K. M.; Lee, S.; Park, M. H.; Roh, S. G. \& Kim, W. Luteolin ameliorates cisplatin-induced acute kidney injury in mice by regulation of p53-dependent renal tubular apoptosis. Nephrol. Dial. Transplant., 26(3):814-22, 2011.

Kavitha, A. V. \& Jagadeesan, G. Role of Tribulus terrestris (Linn.) (Zygophyllacea) against mercuric chloride induced nephrotoxicity in mice, Mus musculus (Linn.). J. Environ. Biol., 27(2 Suppl.):397-400, 2006.

Kavitha, P.; Ramesh, R.; Bupesh, G.; Stalin, A. \& Subramanian, P. Hepatoprotective activity of Tribulus terrestris extract against acetaminophen-induced toxicity in a freshwater fish (Oreochromis mossambicus). In Vitro Cell. Dev. Biol. Anim., 47(10):698-706, 2011.

Keshtmand, Z.; Ghanbari, A.; Khazaei, M. \& Rabzia, A. Protective effect of Tribulus terrestris hydroalcoholic extract against cisplatin-induced apoptosis on testis in mice. Int. J. Morphol. 33(1):279-84, 2015.

Lirdi, L. C.; Stumpp, T.; Sasso-Cerri, E. \& Miraglia, S. M. Amifostine protective effect on cisplatin-treated rat testis. Anat. Rec. (Hoboken), 291(7):797-808, 2008.

Matsushima, H.; Yonemura, K.; Ohishi, K. \& Hishida, A. The role of oxygen free radicals in cisplatin-induced acute renal failure in rats. J. Lab. Clin. Med., 131(6):518-26, 1998.

Naqshbandi, A.; Khan, M. W.; Rizwan, S.; Rehman, S. U. \& Khan, F. Studies on the protective effect of dietary fish oil on cisplatin induced nephrotoxicity in rats. Food Chem. Toxicol., 50(2):26573,2012 
Pabla, N. \& Dong, Z. Cisplatin nephrotoxicity: mechanisms and renoprotective strategies. Kidney Int., 73(9):994-1007, 2008.

Pérez-Rojas, J. M.; Guerrero-Beltrán, C. E.; Cruz, C.; SánchezGonzález, D. J.; Martínez-Martínez, C. M. \& Pedraza-Chaverri, J. Preventive effect of tert-butylhydroquinone on cisplatininduced nephrotoxicity in rats. Food Chem. Toxicol., 49(10):2631-7, 2011.

Phillips, O. A.; Mathew, K. T. \& Oriowo, M. A. Antihypertensive and vasodilator effects of methanolic and aqueous extracts of Tribulus terrestris in rats. J. Ethnopharmacol., 104(3):351-5, 2006.

Ramesh, G. \& Reeves, W. B. TNF-alpha mediates chemokine and cytokine expression and renal injury in cisplatin nephrotoxicity. J. Clin. Invest., 110(6):835-42, 2002.

Ramesh, G. \& Reeves, W. B. TNFR2-mediated apoptosis and necrosis in cisplatin-induced acute renal failure. Am. J. Physiol. Renal Physiol., 285(4):F610-8, 2003.

Ramesh, G. \& Reeves, W. B. Salicylate reduces cisplatin nephrotoxicity by inhibition of tumor necrosis factor-alpha. Kidney Int., 65(2):490-8, 2004.

Rajendar, B.; Bharavi, K.; Rao, G. S.; Kishore, P. V.; Kumar, P. R.; Kumar, C. S. \& Patel, T. P. Protective effect of an aphrodisiac herb Tribulus terrestris Linn on cadmium-induced testicular damage. Indian J. Pharmacol., 43(5):568-73, 2011.

Raoofi, A.; Khazaei, M. \& Ghanbari, A. Protective effect of hydroalcoholic extract of Tribulus terrestris on Cisplatin induced renal tissue damage in male mice. Int. J. Prev. Med., 6:11, 2015.

Saleh, S.; Ain-Shoka, A. A.; El-Demerdash, E. \& Khalef, M. M. Protective effects of the angiotensin II receptor blocker losartan on cisplatin-induced kidney injury. Chemotherapy, 55(6):399406, 2009.

Shalaby, M. A. \& Hammouda, A. A. Assessment of protective and anti-oxidant properties of Tribulus terrestris fruits against testicular toxicity in rats. J. Intercult. Ethnopharmacol., 3(3):113-8, 2014.

Sharma, P.; Huq, A. U. \& Singh, R. Cypermethrin induced reproductive toxicity in male Wistar rats: protective role of Tribulus terrestris. J. Environ. Biol., 34(5):857-62, 2013.

Sheikh-Hamad, D.; Cacini, W.; Buckley, A. R.; Issac, J.; Truong, L. D.; Tsao, C. C. \& Kishore, B. K. Cellular and molecular studies on cisplatin-induced apoptotic cell death in rat kidney. Arch. Toxicol., 78(3):147-55, 2004.

Singh, S.; Nair, V. \& Gupta, Y. K. Evaluation of the aphrodisiac activity of Tribulus terrestris Linn. in sexually sluggish male albino rats. J. Pharmacol. Pharmacother., 3(1):43-7, 2012.
Sugunavarman, T.; Jagadeesan, G. \& Sankar Samipillai, S. Tribulus terrestris extract protects against mercury-induced. J. Ecobiotechnology, 2(1):59-65, 2010.

Ueki, M.; Ueno, M.; Morishita, J. \& Maekawa, N. D-ribose ameliorates cisplatin-induced nephrotoxicity by inhibiting renal inflammation in mice. Tohoku J. Exp. Med., 229(3):195201, 2013.

\author{
Correspondence to: \\ Amir Raoofi \\ Shahid beheshti \\ University of Medical Sciences, \\ Tehran \\ Iran \& Fertility and Infertility Research Center, \\ Kermanshah University of Medical Sciences, \\ Kermanshah \\ IRAN
}

Email: amirrezaraoofi@yahoo.com

Received: 15-10-2016

Accepted: 19-01-2016 